\title{
Immunodynamics of Th17 cells in HIV-1 subtype 'C' infection
}

\author{
Madhu Vajpayee*, Alpana Singh, Sharique A Ali, Neeraj Kumar Chauhan, Ravinder Singh \\ From First International Science Symposium on HIV and Infectious Diseases (HIV SCIENCE 2012) \\ Chennai, India. 20-22 January 2012
}

\section{Background}

Th17 cells are IL-17 producing CD4-T cells which play a vital role in inflammatory responses, antimicrobial defense and autoimmunity. However, the involvement of Th17 cells in HIV-1 infection especially in subtype-C is not yet identified. Thus through this study we try to dissect the role of Th17 cells in HIV-1 subtype 'C' infection.

\section{Methods}

31 HIV seropositive antiretroviral therapy naïve and 8 HIV uninfected healthy control subjects were recruited and characterized as being early, late or slow progressor. Peripheral blood mononuclear cells were isolated from each study subject and stimulated with HIV-1 subtype 'C' gag peptide pool and assessed for IL-17 cytokine producing CD4-T cells using intracellular cytokine staining. All clinical groups were statistically compared by Kruskal-Wallis test and Spearman's correlation coefficient was calculated for correlation of different variables.

\section{Results}

Here we reported that both frequency and functionality of HIV-1 specific Th17 cells were induced in early and slow progressors but were significantly reduced $(p<0.001)$ at late stage of infection in peripheral blood. Also a significant negative correlation $(\rho=0.55$; $\mathrm{P}=0.0004$ ) was observed between HIV-1 plasma viral load and gag specific \%IL-17 production via CD4-T cells.

* Correspondence: mvajpayee@hotmail.com

Department of Microbiology, All India Institute of Medical Sciences, New Delhi, India

\section{Conclusion}

This study showcases a comprehensive picture of Th17 cellular dynamics in HIV-1 subtype-C infection. Further, our data establishes that higher frequencies of HIV specific Th17 cells correlates with better control of viral replication and can be used as immune correlate of protection.

Published: 4 May 2012

doi:10.1186/1471-2334-12-S1-O3

Cite this article as: Vajpayee et al: Immunodynamics of Th17 cells in HIV-1 subtype 'C' infection. BMC Infectious Diseases 2012 12(Suppl 1):O3. and take full advantage of:

- Convenient online submission

- Thorough peer review

- No space constraints or color figure charges

- Immediate publication on acceptance

- Inclusion in PubMed, CAS, Scopus and Google Scholar

- Research which is freely available for redistribution

Submit your manuscript at www.biomedcentral.com/submit 